doi: 10.35339/ekm.2019.01.04

УДК 616.379-008.64-085:615.382.

\author{
А.В. Пасечник, Т.И. Тамм ${ }^{1}$, О.В. Данилова ${ }^{2}$, М.С. Попов \\ ${ }^{1}$ Харьковская медицинская академия последипломного образования \\ ${ }^{2}$ Харьковский городской центр "Диабетическая стопа» \\ ${ }^{3}$ КНП «Городская клиническая больница № 2 имени проф. А.А. Шалимова» \\ Харьковского городского совета

\section{РЕЗУЛЬТАТЫ ЛЕЧЕНИЯ РАН С ПОМОЩЬЮ БОГАТОЙ ТРОМБОЦИТАМИ ПЛАЗМЫ У БОЛЬНЫХ С СИНДРОМОМ ДИАБЕТИЧЕСКОЙ СТОПЫ}

\begin{abstract}
В работе представлены результаты лечения 58 больных с нейропатической и смешанной формой синдрома диабетической стопы (СДС) и наличием ран на стопе с помощью местного применения богатой тромбоцитами плазмы (БТП). Установлено, что клетки крови оказывают благоприятное воздействие на патоморфоз раны, стимулируя развитие грануляционной ткани, источником которой является коллаген I типа и упорядоченный неоангиогенез. Благодаря этому происходит формирование полноценной соединительной ткани и полноценного слоя эпителия, способствующих качественному заживлению ран у больных с осложненными формами СДС.

Ключевые слова: богатая тромбочитами плазма, синдром диабетической стопы, особенности процессов репарации.
\end{abstract}

\section{Введение}

Одной из причин неудовлетворительных результатов лечения осложненных форм синдрома диабетической стопы (СДС) является медленное заживление ран после радикальной хирургической обработки гнойных очагов [1-2]. Из-за анатомических особенностей стопы наложить вторичные швы на рану не всегда возможно [3-4]. Процент осложнений при кожной пластике в виде лизиса и нагноений лоскута составляют 30-50\% [2, 5-8]. В последние годы все чаще появляются публикации о положительном влиянии на процессы репарации стволовых клеток при лечении ран различного генеза [9-11].

Цель данного исследования - определить клиническую эффективность БТП при лечении ран в фазе репарации у больных с нейропатической и смешанной формой СДС.

Материал и методы

Проанализированы результаты лечения ран у 58 больных с нейропатической и смешанной формой СДС в возрасте от 42 до 89 лет. Критериями включения являлись: раны во второй фазе раневого процесса; локализация ран на тыле стопы и окололодыжечной области; раны малых и средних размеров по классификации В.Я. Васюткова (1993); смешанная и нейропатическая формы СДС и наличие у больных сахарного диабета 2 типа. Критериями исключения служили: раны с локализацией в других областях стопы и голени; гнойно-некротические раны; раны больших размеров (26-50 см²); ишемическая форма СДС; наличие у больных СД первого типа.

В качестве обследования использовали общеклинические, биохимические методы исследования. Контроль раневого процесса осуществляли на 10 -е, 20 -е и 30 -е сутки лечения по клиническим признакам: наличие гиперемии и отека краев ран, состояния грануляционной ткани и краевой эпителизации, бактериологического контроля, а также с помощью гистологического и гистохимического исследования краев раны.

Результаты и их обсуждение

Местное применение БТП в ходе лечения начинали тогда, когда в ране прекращалось

(C) А.В. Пасечник, Т.И. Тамм, О.В. Данилова, М.С. Попов, 2019 
гнойное отделяемое, исчезали фибрин и отек ее краев, а площадь раны покрывала зрелая грануляционная ткань. Наряду с клиническими признаками определяли уровень бактериальной обсемененности, который показал, что из 58 больных у 3 (5,1\%) инфицирование раны составило меньше 102КОЕ/г ткани, у 18 (31\%) были выделены единичные колонии и у 37 (66 \%) посев из раны роста не дал.

Через 10 суток лечения БТП у всех больных в ранах были яркие сочные грануляции с выраженной краевой эпителизацией. Сохранялся умеренный отек тканей стопы. При гистологическом исследовании в грануляционной ткани среди клеточной массы преобладали фибробласты. Среди свободных элементов соединительной ткани определялись лимфоциты, гистоциты, небольшое количество нейтрофилов. Кроме того, обнаружены отдельные очаги коллагеновых волокон с расположенными среди них немногочисленными клетками и сосудами. Они состояли преимущественно из коллагена 3-го типа, местами определялись более нежные фибриллярные структуры коллагена 1-го типа. Наличие в клеточной грануляционной ткани волокнистых структур свидетельствует о ее созревании. Эти данные подтверждены подсчетом плотности и диаметра сосудов. Плотность при нейропатической форме составила $(37,4 \pm 8,3)$ ед., при смешанной $(37,8 \pm 10,0)$ ед. Площадь микрососудов составила $(246,75 \pm 77,2)$ и $(242,15 \pm 78,6)$ мкм $^{2}$ при нейропатической и смешанной форме соответственно.

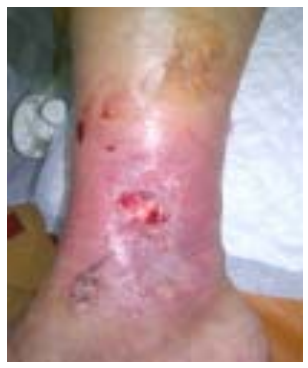

10-е сутки

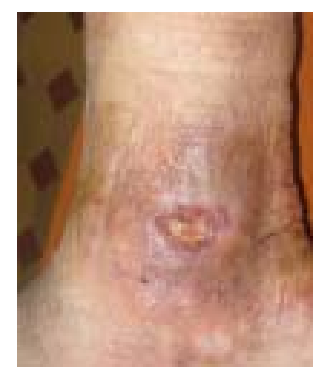

20-е сутки ве межклеточного вещества увеличивалось количество коллагеновых волокон, которые агрегировались в пучки. Иммуногистохимически определялись коллагены 1-го и 3-го типов, представленные в приблизительно равных пропорциях. При том, что плотность микрососудов была достаточно высока, составляя $(23,7 \pm 10,3)$ ед. при нейропатической форме и $(23,35 \pm 10,36)$ ед. при смешанной, диаметр составлял $(344,6 \pm 126,7)$ мкм² при нейротрофической форме и $(345,2 \pm 128,8)$ мкм $^{2}$ при смешанной.

Кровеносные сосуды были полнокровны, в них хорошо различались отдельные эритроциты. Эндотелиоциты, выстилающие просветы сосудов, имели уплощенную форму, межэндотелиальные щели отсутствовали. Вследствие этого общее состояние тканей характеризовалось отсутствием значимого отека.

Все вышеперечисленное создавало условия для более качественной реэпителизации. Многослойный плоский эпителий покрывал большую часть раневого дефекта.

На 30-е сутки у всех пациентов с малыми ранами (28 человек) отмечено заживление раневого дефекта с образованием эпителиального слоя (рис. 1).

При изучении биоптатов ран в эти сроки отмечалась полная эпителизация раневого дефекта. Эпителиальный пласт имел среднюю толщину, четкую дифференцировку слоев. В базальном слое определялась умеренная пролиферативная активность клеток, в клетках поверхностного слоя определялся кератогиа-

Рис. 1. Больная И. Динамика заживления раны под воздействием ОТП

На 20-е сутки клинически определялись признаки продолжающейся эпителизации краев раны и во всех случаях присутствовала хорошо развитая грануляционная ткань.

В биоптатах ран в эти сроки отмечалось наличие грануляционной ткани с мощным развитием кровеносных сосудов и пролиферацией фибробластов, которые были ориентированы параллельно поверхности раны. В соста- лин, очагово отмечались признаки начальной кератинизации. Участки дермы, ранее являвшиеся раневым дефектом, состоят из равномерно васкуляризованной грубоволокнистой соединительной ткани. Последняя построена из пучков переплетающихся коллагеновых волокон, имеющих тенденцию к продольной ориентации относительно эпидермиса (рuс. 2). Коллагеновые волокна представлены преиму- 


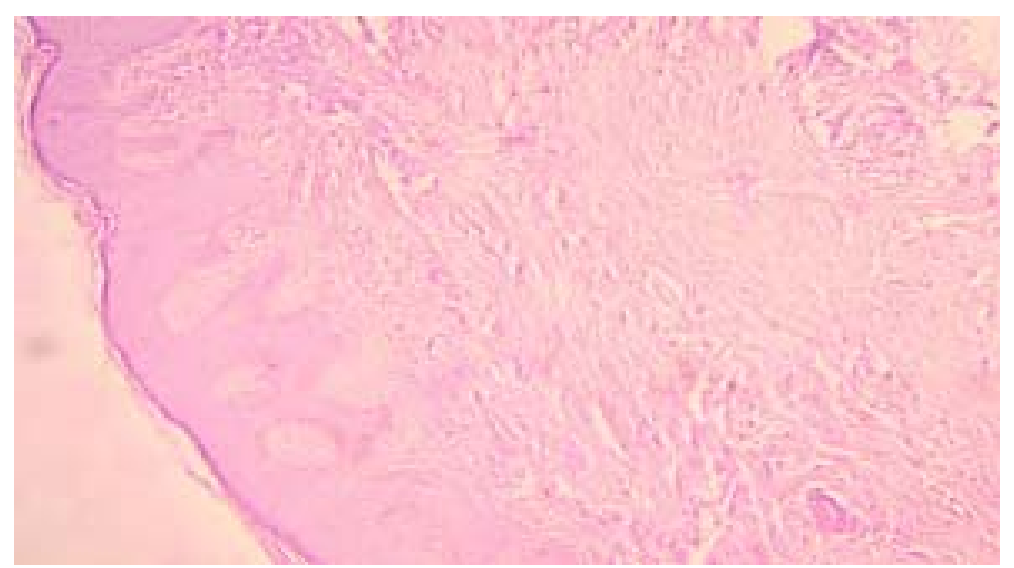

Рис. 2. Гистоструктура раны на 30 -е сутки лечения БТП. Рубцовая ткань

с продольной ориентацией волокон, покрытая зрелым эпидермисом с признаками кератинизации. Гематоксилин+эозин. $\times 100$

щественно зрелым 1-м типом коллагена, коллаген 3-го типа определялся очагово, ближе к глубоким слоям дермы.

Клеточный состав соединительной ткани представлен преимущественно фиброцитами зрелыми, функционально неактивными клетками фибропластического домена. Кровеносные сосуды имели капиллярный тип строения, округлую или овальную форму, четко выраженную базальную мембрану, на которой расположены уплощенные эндотелиоциты, компактно пригнанные друг к другу (puc. 3). Плотность микрососудов в тканях данной группы при нейротрофической форме составила $(14,2 \pm 4,4)$ ед., при смешанной - $(14,1 \pm 4,1)$ ед. в поле зрения. Усредненная площадь сосуда при нейротрофической форме была $(479,5 \pm$ $\pm 138,9)$ мкм $^{2}$, при смешанной - $(484,3 \pm 136,4)$ мкм² (таблиця).
Учитывая тот факт, что в основе развития грануляционной ткани лежат процессы ангиогенеза, произведено целенаправленное исследование неоангиогенеза при нейропатической и смешанной формах СДС. В качестве критериев развития ангиогенеза использовали подсчет плотности микрососудов (ПМ) и площади сосуда (ПлС). Результаты исследования представлены в таблице. Установлено, что показатели неоангиогенеза в структуре грануляционной ткани при этих двух формах СДС под воздействием БТП не имеют достоверной разницы по плотности микрососудов и площади сосуда в исследуемые сроки. Следует отметить, что у пациентов со смешанной и с нейропатической формой, под воздействием БТП отмечено достоверное уменьшение плотности микрососудов и, почти в два раза, увеличение площади сосудов.

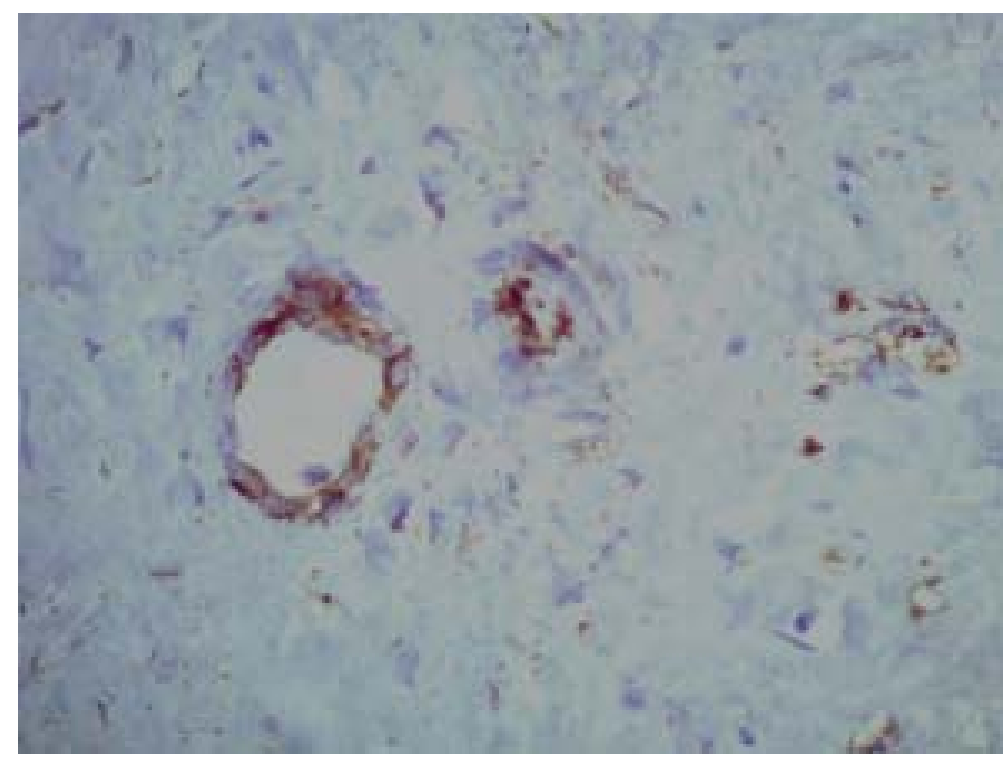

Рис. 3. Гистоструктура раны на 30-е сутки лечения БТП. Кровеносный сосуд округлой формы с компактным эндотелием. Иммуногистохимическая реакция с CD34+гематоксилин. $\times 400$ 
Сравнительные параметры васкуляризации грануляцуионной ткани из ран у больных нейропатической и смешанной формой СДС под воздействием БТП

\begin{tabular}{|c|c|c|c|c|}
\hline \multirow{2}{*}{ Сроки } & \multicolumn{2}{|c|}{ Нейропатическая форма } & \multicolumn{2}{|c|}{ Смешанная форма } \\
\hline & ПМ (ед.) & ПлС $\left(\right.$ мкм $\left.^{2}\right)$ & ПМ (ед.) & ПлС $\left(\mathrm{мкм}^{2}\right)$ \\
\hline 10-е сут. & $37,4^{*} \pm 8,3$ & $246,750^{* *} \pm 77,20$ & $37,80^{*} \pm 10,00$ & $242,15^{* *} \pm 78,60$ \\
\hline 20-е сут. & $23,7^{*} \pm 10,3$ & $344,60^{* *} \pm 126,70$ & $23,35^{*} \pm 10,36$ & $345,20^{\star *} \pm 128,80$ \\
\hline 30-е сут. & $14,2^{*} \pm 4,4$ & $479,50^{* *} \pm 138,90$ & $14,10^{*} \pm 4,10$ & $484,30^{* *} \pm 136,40$ \\
\hline
\end{tabular}

Примечание. ПМ - плотность микрососудов * $\mathrm{p}>0,05$. ПлС - площадь сосуда ** $\mathrm{p}>0,05$.

На 30-е сутки терапии у 13 больных с ранами средних размеров и у всех 28 больных с ранами малых размеров наблюдалась полная реэпителизация раневого дефекта. Этот процесс сопровождался снижением плотности микрососудов при увеличении средней площади сосуда. Также у этих больных наблюдался более совершенный коллагеногенез.

На 30-е сутки лечения у 17 (56\%) из 30 больных с ранами средних размеров, площадь которых исходно составляла 20-22 см², не было зарегистрировано случаев полного закрытия раневого дефекта. При этом на фоне ярких сочных грануляций краевая эпителизация была замедленной. Этим пациентам закрытие раневой поверхности произведено методом аутодермопластики по Тиршу. Во всех случаях отмечено приживление кожных лоскутов с закрытием раневой поверхности.

Анализ результатов исследования показал, что местное применение БТП в фазе репарации у больных со смешанной и нейропатической формой СДС оказывает существенное влияние на стимуляцию процессов неоангио- генеза и коллагеногенеза. Под воздействием БТП в качестве источника созревания соединительной ткани выступает коллаген I типа и более упорядоченный процесс местного неоангиогенеза. Упорядоченный ангиогенез способствует более завершенному коллагеногенезу в виде явного преобладания зрелого коллагена I типа. Коллагеновые волокна в свою очередь являются опорным каркасом для регенерирующего эпителия. Эти два фактора способствуют формированию полноценной соединительной ткани и морфологически состоятельного слоя эпителия.

\section{Выводы}

1. Местное применение БТП при лечении ран в фазе репарации у больных с синдромом диабетической стопы оказывает положительный эффект за счет формирования зрелой соединительной ткани и полнослойного эпителия.

2. Терапевтический эффект использования БТП при лечении ран у больных СДС проявляется в одинаковой мере как при нейропатической, так и смешанной формах.

\section{Литература}

1. Armstrong DG. Diabetic foot ulcers and their recurrence / DG. Armstrong, AJM. Boulton, SA. Bus // N Engl J Med. - 2017. - № 376. - P. 2367-2375.

2. Zubair M. Diabetic Foot Ulcer: A Review / M. Zubair, A. Malik, J.Ahmad // Am J Internal Med. 2015. - Vol. 3, № 2. - P. 28-49.

3. Герасимов Г. Н. Результаты модифицированного способа аутодермопластики вяло гранулирующих ран и трофических язв нижних конечностей / Г. Н. Герасимов // Экпериментальная и клиническая медицина. - 2015. - № 3 (68). - С. 135-138.

4. Стряпухин В. В. Хирургическое лечение диабетической стопы / В. В. Стряпухин, А. Н. Лишенко // Хирургия. - 2011. - № 2. - С. 73-78.

5. Грекова Н. М. Диагностика и хирургическое лечение синдрома диабетической стопы: учебное пособие / Грекова Н. М., Бордуновский В. Н., Гурьева И. В. - Челябинск, 2010. - 112 с.

6. Игнатович И. Н. Обоснование оптимального метода лечения пациентов с нейроишемической формой синдрома диабетической стопы на основании сравнения отдаленных результатов применения различных методов / И. Н. Игнатович, Г. Г. Кондратенко, Д. Д. Никулин // Новости хирургии. 2013. - Том 21, № 2. - С. 69-75.

7. Оптимізація лікування хворих з приводу хронічних ран / С. В. Малик, Я. В. Рибалка, О. С. Осіпов, А. В. Верба // Клінічна хірургія. - 2017. - № 10. - С. 49-50.

8. International Working Group on the Diabetic Foot. IWGDF guidance on the diagnosis and management of foot infections in persons with diabetes. / B.A. Lipsky, J. Aragon-Sanchez, M. Diggle et al. // Diabetes Metab Res Rev. - 2016. - № 32 (Suppl. 1). - P. 45-74. 
9. Просянникова Н. В. Эффективность лечения длительно незаживающих ран и язв кожи методом аутологичной богатой тромбоцитами плазмы / Н. В. Просянникова // Врач скорой помощи. 2013. - № 2. - C. 42-46.

10. Marx R.E. Platelet-rich plasma. Growth factor enhancement for bone grafts / R. E. Marx, E. R. Carlson, R. M. Eichstaedt et al. // Oral Surg Oral Med Oral Pathol Oral Radial Endod . - 1998. № 85. - P. 638-646.

11. Параскевич В. Л. Применение обогащенной тромбоцитами и фибрином плазмы крови для закрытия послеоперационных ран / В. Л. Параскевич // Стоматологический журнал. - 2005. - № 6. C. 53-55.

\section{Reference}

1. Armstrong DG., Boulton AJM., Bus SA. (2017). Diabetic foot ulcers and their recurrence. $N$ Engl J Med., № 376, pp. 2367-2375.

2. Zubair M., Malik A., Ahmad J. (2015). Diabetic Foot Ulcer: A Review. Am J Internal Med., vol. 3, № 2, pp. 28-49.

3. Gerasimov G.N. (2015). Rezultatyi modifitsirovannogo sposoba autodermoplastiki vyalo granuliruyuschih ran i troficheskih yazv nizhnih konechnostey [The results of the modified method autodermoplastiki sluggishly granulating wounds and trophic ulcers of the lower extremities]. Ekperimentalnaya i klinicheskaya meditsina - Experimental and Clinical Medicine, vol. 3, № 68, pp. 135-138 [in Russian].

4. Stryaphin V.V., Lishenko A.N. (2011). Hirurgicheskoe lechenie diabeticheskoy stopyi [Surgical treatment of diabetic foot]. Hirurgiya - Surgery, № 2, pp.73-78 [in Russian].

5. Grekova N.M., Bordunovskiy V.N., Gureva I.V. (2010). Diagnostika i hirurgicheskoe lechenie sindroma diabeticheskoy stopyi [Diagnosis and surgical treatment of diabetic foot syndrome]. Chelyabinsk, 112 p. [in Russian].

6. Ignatovich I.N., Kondratenko G.G., Nikulin D.D. (2013). Obosnovanie optimalnogo metoda lecheniya patsientov s neyroishemicheskoy formoy sindroma diabeticheskoy stopyi na osnovanii sravneniya otdalennyih rezultatov primeneniya razlichnyih metodov [Substantiation of the optimal method of treating patients with the neuroischemic form of diabetic foot syndrome based on a comparison of the long-term results of using various methods]. Novosti hirurgii - Surgery news, vol. 21, № 2, pp. 69-75 [in Russian].

7. Malik S.V., Ribalka Ya.V., OsIpov O.S., Verba A.V. (2017). Optimizatsiya likuvannya hvorih z privodu hronichnykh ran [Optimization of treatment for patients with chronic wounds]. Klinichna hirurgiya Clinical surgery, № 10, pp. 49-50 [in Ukrainian].

8. Lipsky B.A., Aragon-Sanchez J., Diggle M. et al. (2016). International working group on the Diabetic Foot. IWGDF guidance on the diagnosis and management of foot infections in persons with diabetes. Diabetes Metab Res Rev, vol. 32 (Suppl. 1), pp. 45-74.

9. Prosyannikova N.V. (2013). Effektivnost lecheniya dlitelno nezazhivayuschih ran i yazv kozhi metodom autologichnoy bogatoy trombotsitami plazmyi [Efficiency of treatment of long-term non-healing wounds and ulcers of the skin by the method of autologous plasma-rich platelets]. Vrach skoroy pomoschiAmbulance doctor. № 2, pp. 42-46 [in Russian].

10. Marx R.E., Carlson E.R., Eichstaedt R.M. et al. (1998). Platelet-rich plasma. Growth factor enhancement for bone grafts. Oral Surg Oral Med Oral Pathol Oral Radial Endod, vol. 85, pp. 638646.

11. Paraskevich V.L. (2005). Primeneniye obogashchennoy trombotsitami i fibrinom plazmy krovi dlya zakrytiya posleoperatsionnykh ran [Use of blood plasma enriched with platelets and fibrin to close postoperative wounds]. Stomatologicheskiy zhurnal - Dental journal, № 6, pp. 53-55 [in Russian].

\section{О.В. Пасічник О.В., Т. І. Тамм, О. В. Данилова, М. С. Попов \\ РЕЗУЛЬТАТИ ЛІКУВАННЯ РАН ЗА ДОПОМОГОЮ БАГАТОЇ ТРОМБОЦИТАМИ ПЛАЗМИ У ХВОРИХ ІЗ СИНДРОМОМ ДІАБЕТИЧНОЇ СТОПИ}

У роботі представлені результати лікування 58 хворих з нейропатичною та змішаною формою синдрому діабетичної стопи (СДС) і наявністю ран на стопі за допомогою місцевого застосування багатої тромбоцитами плазми (БТП). Встановлено, що клітини крові сприятливо впливають на патоморфоз рани, стимулюючи розвиток грануляційної тканини, джерелом якої є колаген I типу і упоряд- 
кований неоангіогенез. Завдяки цьому відбувається формування повноцінної сполучної тканини і повноцінного шару епітелію, що сприяє якісному загоєнню ран у хворих з ускладненими формами СДС.

Ключові слова: багата тромбочитами плазма, синдром діабетичної стопи, особливості проц̧есів репараціï.

\section{O.V. Pasichnyk, T.I. Tamm, O.V. Danilova, M.S. Popov \\ RESULTS OF TREATMENT OF RAS BY USING MULTI PLASMA THROMBOCYTIC IN PATIENTS WITH SYRAIN DIABETIC STOP}

The paper presents the results of treatment of 58 patients with neuropathic and mixed SDS with the presence of wounds on the foot using topical BTP. It has been established that blood cells have a beneficial effect on the pathomorphosis of a wound, stimulating the development of granulation tissue, the source of which is type I collagen and ordered neoangiogenesis. Due to this, the formation of a full-fledged connective tissue and a full-fledged layer of the epithelium, contributing to quality wound healing in patients with complicated forms of SDS.

Keywords: platelet-rich plasma, diabetic foot syndrome, features of reparation processes.

Надійшла до редакиії 14.02.2019

\section{Контактна інформація}

Пасічник Олександр Васильович - старший лаборант кафедри хірургії і проктології Харківської медичної академії післядипломної освіти.

Адреса: Україна, 61176, м. Харків, вул. Амосова, 58.

Тел.: +380509030237.

E-mail:drpasechnyk@gmail.com.

ORCID: 0000-0002-4199-0114.

Тамм Тамара Іванівна - доктор медичних наук, професор, завідувач кафедри хірургії і проктології Харківської медичної академії післядипломної освіти.

Адреса: Україна, 61176, м. Харків, вул. Амосова, 58.

Тел.: +380506379002.

E-mail: tamm_ti@ukr.net.

ORCID: 0000-0001-6372-2092.

Данилова Ольга Вікторівна - лікар-хірург Харківського міського центру «Діабетична стопа» на базі КНП «Міська клінічна лікарня № 2 імені проф. О.О. Шалімова» Харківської міської ради.

Адреса: Україна, 61037, м. Харків, просп. Московський, 197.

Тел.: +380509570679.

E-mail: oldad765@gmail.com.

ORCID: 0000-0002-0253-6058.

Попов Максим Сергійович - завідувач хірургічним відділенням № 3 КНП «Міська клінічна лікарня № 2 імені проф. О.О. Шалімова» Харківської міської ради.

Адреса: Україна, 61037, м. Харків, просп. Московський, 197.

Тел.: +380958022935.

E-mail:Maxutake@yandex.ru.

ORCID: 0000-0002-7731-4281. 